УДК $94(470)$ «1953-1963»

DOI 10.18413/2687-0967-2020-47-1-160-169

\title{
ОСОБЕННОСТИ НОРМАТИВНО-ПРАВОВОГО РЕГУЛИРОВАНИЯ ГОСУДАРСТВЕННО-ЦЕРКОВНЫХ ОТНОШЕНИЙ В СССР (1953-1963)
}

\author{
PECULIARITIES OF THE NORMATIVE-LEGAL REGULATION \\ OF THE STATE-CHURCH RELATIONS IN THE USSR (1953-1963)
}

\author{
Н.В. Остроухова \\ N.V. Ostroukhova \\ Белгородский государственный национальный исследовательский университет, \\ Россия, 308015, г. Белгород, ул. Победы, 85 \\ Belgorod State National Research University, \\ 85 Pobeda St, Belgorod, 308015, Russia \\ E-mail: 108805@bsu.edu.ru
}

\begin{abstract}
Аннотация
В статье проанализированы причины свѐртывания политики частичной либерализации со стороны государства по отношению к Русской Православной Церкви (далее РПЦ), обусловившие изменение нормативно-правового регулирования государственно-церковных отношений в СССР в 1953-1963 гг. по сравнению с послевоенным десятилетием. Историографический анализ причин возврата Н.С. Хрущева к политике гонения на РПЦ, а также изучение нормативно-правовой базы регулирования конфессиональной политики способствовали формированию мнения автора о том, что ужесточение антирелигиозной кампании совпало со свертыванием «оттепели» и нарастанием волюнтаристских решений Хрущева. Главной целью новой антирелигиозной кампании было стремление главы государства отвлечь внимание общественности от нарастающих проблем, вызванных его грубыми просчетами в экономическом курсе внутри страны и негативных последствий политических ошибок на международной арене.
\end{abstract}

\begin{abstract}
The article analyzes the reasons for overthrowing the policy regarding private-liberal relations between Russia and the Orthodox Church (hereinafter referred to as the Russian Orthodox Church), causing a change in the legal regulation of state-church relations in the USSR in 1953-1963 compared to the post-war decade. Historiographic analysis of the reasons for the return N.S. Khrushchev's attitude towards the policy of persecution of the Russian Orthodox Church, as well as the study of the legal and regulatory framework for the regulation of confessional policies, contributed to the author's opinion that the toughening of the antireligious campaign coincided with curtailing the «thaw» and the growth of Khrushchev's voluntaristic decisions. The main goal of the new anti-religious campaign was the desire of the head of state to divert public attention from the growing problems caused by his gross miscalculations in the economic course within the country and the negative consequences of political mistakes in the international arena. The brutal administrative and command pressure on the church often had the opposite effect on the expectations of the authorities, aroused criticism from the intelligentsia of the domestic leadership policy, and outraged the broad masses of ordinary citizens who expected continued partial liberalization of the Soviet regime in the context of the «thaw» policy and reforms undertaken in 1950 years.
\end{abstract}

Ключевые слова: советское государство, Русская Православная Церковь, духовенство, верующие, государственно-церковные отношения, верующие, антирелигиозная политика.

Key words: soviet government, Russian Orthodox Church, the clergy, believers, state-church relations, anti-religious policy. 
Обращение к проблеме изменения нормативно-правового регулирования государственно-церковных отношений в СССР в 1953-1964 гг. по сравнению с послевоенным десятилетием дает возможность осмыслить причины свѐртывания политики частичной либерализации со стороны государства по отношению к Русской Православной Церкви (далее РПЦ). Актуальность данной проблемы, прежде всего, состоит в том, чтобы извлечь уроки из негативного исторического опыта государственного вмешательства в религиозную жизнь общества с целью ее регулирования административно-командными методами. Современные события на Украине, связанные с церковным расколом, в еще большей степени актуализируют заявленную проблему.

Методология исследования взаимоотношений советской власти и Русской Православной церкви в 1953-1963 гг. основана на основополагающих принципах исторического познания: принципе историзма, системном подходе, принципе объективности и ценностном подходе, проблемно-хронологическом принципе. В процессе подготовки статьи применялись сравнительно-исторический, хронологический методы исследования.

В отечественной историографии период с 1943 по 1953 гг. принято считать периодом частичного смягчения (или либерализации) государственно-церковных отношений [Алексеев, 1991; Цыпин, 1997; Васильева, 2001; Одинцов, 2002; Шкаровский, 1999, 2010 ]. Однако усиление авторитета и материальной базы РПЦ, ставшее следствием частичной либерализации государственно-церковных отношений при В.И. Сталине, после его смерти вызывало недовольство партийных структур как в центре, так и на местах. В результате, начиная с 1953 года, вновь, как в 1920-е годы, вопросы тотального регулирования и государственного контроля конфессиональной политики стали перемещаться в сферу влияния КПСС. При этом в партийном руководстве при выстраивании взаимоотношений с РПЦ сложились антирелигиозный и «государственный» подходы. Последний предполагал включение РПЦ в систему управления государства [Шкаровский, 2010, с. 351].

С приходом к власти Н.С. Хрущева в СССР вновь резко активизируется антирелигиозная пропаганда. Н.С. Хрущев как первый секретарь ЦК КПСС во внутренней политике стремился в рамках развернутой им политики «десталинизации» до некоторой степени смягчить советский режим во всех сферах общественной жизни. Практическая реализация данной политики воплотилась в ликвидации системы ГУЛАГа, реформах суда и прокуратуры, частичной реабилитации политических заключенных, в отказе от силовых методов осуществления революционных преобразований за рубежом, в предпринятой попытке наладить позитивный контакт власти с научной и творческой интеллигенцией, в смягчении идеологической цензуры. Однако не решенным оставался вопрос определения курса на дальнейшее развитие взаимоотношений советского государства и РПЦ в условиях мирного времени.

Как показала история, было бы вполне естественным в условиях частичного смягчения политического диктата партийно-государственных структур в общественной жизни СССР сохранить наметившиеся в годы Великой Отечественной войны позитивные тенденции во взаимоотношениях советского государства с РПЦ, имевшие место и в первое послевоенное десятилетие. Моральный авторитет РПЦ являлся важным ресурсом, который советская власть могла бы использовать при реализации политики сплочения сил рабочего, профсоюзного, пацифистского движений, создания на этой основе единого демократического фронта на международной арене, а также для укрепления духовно - нравственных основ советского общества.

РПЦ, которая в ходе Великой Отечественной войны оказывала всевозможную патриотическую моральную и материальную поддержку государственным структурам, мобилизующим народ на отпор агрессору, после окончания боевых действий рассматривалась народом в качестве одного из главных идейных вдохновителей победы над гитлеровским блоком.

Если И.В. Сталин в критических условиях первого периода Великой Отечественной войны вынужден был удовлетворить общественные ожидания частичной либерализации в конфессиональной политике советского государства, смог начать реализацию т. н. «политики перемирия» во взаимоотношениях с РПЦ, то Н.С. Хрущев сознательно пошел 
на раскол гражданского общества в СССР, вернувшись к жесткой линии «богоборчества» по отношению к религиозным организациям. Вместе с тем причины возврата Н.С. Хрущева к репрессивной политике по отношению к РПЦ не вполне ясны.

Поскольку РПЦ и символически, и институционально была связана с монархией, советская власть стремилась лишить ее прежде всего материальных ресурсов. Уже в первое революционное десятилетие наиболее ценное церковное имущество было национализировано, важнейшие соборы РПЦ получили статус памятников архитектуры. Значительная часть ценностей из конфискованного церковного имущества была передана государственным музеям, то есть «переведена в пространство культуры, не смежное с политикой» [Растимешина, 2012]. Таким образом, к середине 1950-х годов РПЦ экономически была зависима от советского государства, и поэтому не могла предоставить материальную поддержку для потенциальной оппозиции существующей власти.

Можно предположить, что Н.С. Хрущев опасался объединения усилий РПЦ с зарубежными единоверцами, придерживающимися антисоветских установок, прежде всего с Русской Зарубежной Церковью, а также Поместными Православными Церквами: Константинопольской, Александрийской, Антиохийской, Кипрской, Иерусалимской, Сербской, Румынской, Греческой, Кипрской, Албанской, Польской, Чешских земель и Румынии, Болгарской, Православной Церковью Америки.

В современной отечественной историографии до сих пор нет единого мнения о причинах возврата Н.С. Хрущева к политике гонения на РПЦ. Дискуссия по этому вопросу ведется по нескольким направлениям.

Такие историки, как Маслова [2005], Пыжиков [2002], Набиев и др. [2013] придерживаются точки зрения, что религия рассматривалась Н.С. Хрущевым и его окружением как канал проникновения идейно-чуждых воззрений, который мог стать важным фактором политической нестабильности социалистической политической системы как в СССР, так и в странах «социалистического лагеря». Тем более что проводимые под руководством Н.С. Хрущева мероприятия по частичной либерализации общественных отношений в СССР и ослабление политической цензуры стали благоприятной почвой для формирования внутренней и внешней оппозиции. Кроме того, руководство СССР было серьезно обеспокоено усилением религиозных настроений в советском обществе, в том числе среди значительной части выпущенных на свободу заключенных ГУЛАГа и столичной интеллигенции. В этой связи исследовавший данную проблему протоиерей Цыпин [1994, 1997] считает одним из определяющих факторов, повлиявшим на резкое обострение государственно-церковных отношений при Хрущеве, начавшееся еще в годы Великой Отечественной войны «возрастающее влияние церкви». Овчинников [2015, с. 78] также считает, что ужесточение государственной политики в отношении Церкви было связано с усилением значения религии в жизни граждан.

Другая группа историков [Шкаровский, 2010, с. 352; Васильева, 2004; Марченко, 2008; Гераськин, Михайловский, 2010] придерживаются мнения, что резкая активизация атеистической пропаганды и антирелигиозной политики связана с реализацией поставленной Н.С. Хрущевым цели построения в СССР материально-технической базы коммунизма. Воинственный атеизм был с большой долей вероятности обусловлен также принятием морального кодекса строителя коммунизма. То есть в условиях коммунистического строительства в СССР и курса на «мирное сосуществование двух политических систем», принятого на ХХ съезде КПСС в 1956 г., по мнению советского политического руководства, необходимость в христианской идеологии в будущем коммунистическом обществе полностью отпадала, и идея атеистического воспитания граждан СССР оказалась доминирующей.

Часть исследователей [Штриккер, 1995; Чумаченко, 1999; Фурман, 2011; Одинцов, 2002; Дорош, 2018] считает, что воинствующий атеизм Н.С. Хрущева был связан с внутрипартийной борьбой за власть. Некоторое ослабление давления на РПЦ, приведшее к относительной стабилизации государственно-церковных отношений в СССР при Сталине, преподносилось самим Хрущевым и сторонниками «десталинизации» в его окружении 
как негативное сталинское наследие, которое следует ликвидировать, чтобы «отмежеваться» от «преступлений эпохи культа личности». Положение усугублялось тем обстоятельством, что значительная часть иерархов РПЦ и простых прихожан были признательны Сталину за определенный отход от политики воинствующего атеизма. Хрущев же в контексте проводимой им политики «развенчания культа личности» яростно боролся в том числе и с уважительной памятью населения о Сталине. Кроме того, реализация курса на «десталинизацию» помогала постепенно убирать из властных структур наиболее ярких соратников Сталина, представлявших серьезную конкуренцию самому Хрущеву.

В своей борьбе с соратниками Сталина в Президиуме ЦК КПСС Хрущев опирался на группу новых представителей партийно-государственной номенклатуры, имевших крайне антирелигиозные идеологические взгляды, таких как М.А. Суслов, Е.А. Фурцева, П.Н. Поспелов, Л.Ф. Ильичева, а также молодых руководителей ВЛКСМ. Так, исследовавший данную проблему Одинцов [2002] считает, что антирелигиозная политика Н.С. Хрущева была обусловлена борьбой за власть в составе высшей номенклатуры и в руководстве спецслужб. С другой стороны, историк Дорош [2018] доказывает, что при формировании дальнейшего курса во взаимоотношениях РПЦ с советским государством после смерти Сталина в 1953 г. существенную роль сыграло противоборство носителей идеологии «воинствующего атеизма» (Н.С Хрущев, М.А. Суслов, П.Н. Поспелов, Л.Ф. Ильичев и др.) и сторонников более мягкой модели «сосуществования» РПЦ и советского государства, избранной Сталиным и его ближайшим окружением (К.Е. Ворошиловым, Г.М. Маленковым, В.М. Молотовым и др.) еще в 1940-е годы под влиянием Великой Отечественной войны.

Как показывает анализ отечественной исторической литературы, авторы при аргументации своей позиции опираются на значительный пласт опубликованных нормативноправовых источников. При подготовке материала статьи были также проанализированы неопубликованные архивные материалы фонда Уполномоченного Советов по делам РПЦ и религиозных культов при СМ СССР по Белгородской области, в том числе руководящие указания и информационные материалы по вопросам деятельности религиозных обществ, церквей РПЦ ${ }^{89}$.

Первым документом, в котором пересматривалась и квалифицировалась как «примиренческая» прежняя сталинская политика в религиозном вопросе, стало «постановление ЦК КПСС «О крупных недостатках в научно-атеистической пропаганде и мерах ее улучшения»») [Постановление ЦК КПСС 07.07.1954].

Практическая реализация постановления вызвала недовольство не только среди духовенства и прихожан. Г.М. Маленков, К.Е. Ворошилов, В.М. Молотов, которые пытались продолжить начатый при Сталине курс на интегрирование РПЦ в структуру государственной системы СССР, считали, что очередная антирелигиозная война вызовет крайне нежелательные последствия как внутри страны, так и за рубежом. «Прибывший в СССР в сентябре 1954 года Антиохийский Патриарх также просил прекратить перегибы в отношении церкви, поскольку это, по его мнению, затрудняло работу по сближению между церквами и народами» [Шкаровский, 2010, с. 353].

В результате в условиях борьбы Хрущева за упрочение своей власти давление на Церковь временно ослабло, что нашло выражение в принятом 10 ноября 1954 года постановлении ЦК КПСС «Об ошибках в проведении научно-атеистической пропаганды среди населения» [Постановление ЦК КПСС 10.11.1954]. В тексте постановления отмечалось, что научно-атеистическая пропаганда материалистического мировоззрения не должна была сопровождаться оскорблением чувств верующих и административным произволом. Таким образом, ревизия сталинского курса в проведении конфессиональной политики в СССР под давлением обстоятельств руководством Н.С. Хрущева была временно отложена. Кроме того, в соответствии с постановлением Совета Министров СССР от 17 февраля 1955 года «Об изменении порядка открытия молитвенных зданий», Совет по делам РПЦ

\footnotetext{
${ }^{89}$ Государственный архив Белгородской области (ГАБО). Ф.Р - 1179. Оп. 2.
} 
наделялся правом регистрации приходских общин, действовавших без официального разрешения [Шкаровский, 2010, с. 353].

Развернувшийся в стране общий процесс частичной либерализации первоначально благотворно сказался на положении РПЦ. Выживших в лагерях и тюрьмах священнослужителей стали выпускать на свободу по амнистии, а затем и по реабилитации.

Однако после ХХ съезда КПСС политическое положение Хрущева упрочилось, и в партийных документах вновь появились антицерковные установки.

Во-первых, 16 октября 1958 года Совет Министров СССР принял постановления «О монастырях в СССР» и «О налоговом обложении доходов предприятий епархиальных управлений, а также доходов монастырей» [Законодательство, 1971, с. 35-36]. Реализация данных нормативных актов предполагала сокращение количества обителей, уменьшение земельных наделов, запрет на применение наемного труда в монастырях, возобновление сбора налогов со строений при существенном росте ставок, увеличение земельной ренты ${ }^{90}$. Данные нормативные акты вносили дезорганизацию в экономическую жизнь церкви, приходы разорялись.

Во-вторых, принятое 4 октября 1958 года секретное постановление ЦК КПСС «О недостатках научно-атеистической пропаганды» предписывало усилить борьбу с «религиозными пережитками» советских людей. Постановление адресовалось всем партийным, общественным организациям, государственным органам. [Чумаченко, 2014, с. 83]. В ноябре-декабре 1958 года началась новая волна массовой чистки церковных библиотек, сопровождавшаяся усилением цензуры. Для ограничения поступления новых изданий была выпущена специальная «Инструкция о порядке пропуска в СССР религиозной литературы и предметов религиозного культа» [Шкаровский, 2018, с. 22].

В-третьих, 28 ноября 1958 года ЦК КПСС принял постановление «О мерах по прекращению паломничества к так называемым ”святым местам $\rightarrow$ [Шкаровский, 2010, с. 363]. Местными органами власти применялись разнообразные методы борьбы с паломничеством верующих. Например, участок, на котором располагались водоисточники бывшего монастыря «Коренная Пустынь», распоряжением Курского облисполкома был передан ремесленному училищу по механизации сельского хозяйства. Участок был огорожен, источники дренажированы в реку, произведены посадки плодовых и декоративных деревьев ${ }^{91}$. На местах директивы из центра проводились весьма жестко. Так, в докладной записке уполномоченного Совета по делам РПЦ по Белгородской области А. Сорочкина от 25.05.1959 г. «О проведенных мероприятиях по прекращению паломничества в с. Устинке», направляемой в Совет по делам РПЦ при СМ СССР, подробно изложена процедура борьбы с паломничеством верующих к «святому колодцу» ${ }^{92}$. В записке уполномоченного отмечено, что паломничество в с. Устинке Шебекинского района не состоялось благодаря правильной организации массово-политической работы среди населения. Выполняя указание бюро обкома КПСС, Шебекинский райисполком, хотя и с большим опозданием, вынес решение о засыпке так называемого «святого колодца», его уничтожении за несколько дней до праздников. Помимо мер разъяснительного характера, предпринимаемых представителями сельских и колхозных парторганизаций в населенных пунктах «вероятного сосредоточения паломников» с 18 по 22 мая 1959 года, для поддержания общественного порядка во всех населенных пунктах, расположенных по трассе Белгород - Шебекино, были организованы круглосуточные посты милиции и дежурство депутатов сельского Совета ${ }^{93}$. По мнению уполномоченного Совета по Белгородской области А. Сорочкина, такие меры имели свое положительное значение.

\footnotetext{
${ }^{90}$ ГАБО. Ф. Р - 1179. ОП. 2. Д. 1. Л. 34

${ }^{91}$ ГАБО. Ф. Р - 1179. ОП. 2. Д. 3. Л. 40.

${ }^{92}$ ГАБО. Ф. Р - 1179. ОП. 2. Д. 2. Л. 58.

${ }^{93}$ Там же. Л. 58-59.
} 
Помимо перечисленных мер вновь возобновилось массовое закрытие храмов. В одном только 1958 году в СССР была снята с регистрации 91 приходская община [Шкаровский, 2010, с. 363-364]. При этом под угрозой привлечения к уголовной ответственности по ст. ст. 123 и 169 УК РСФСР и соответствующим статям УК союзных республик запрещалось проведение религиозных обрядов лицами, не имеющими духовного сана ${ }^{94}$.

На ХХІ съезде КПСС, проходившем в январе-феврале 1959 года, Хрущев в своем докладе определил преодоление религиозных пережитков в народном сознании в качестве одной из главных задач предстоящей семилетки. Реализуя его установки, в инструктивном письме Совета по делам РПЦ своим уполномоченным от 12 июня 1959 г. формулировалось требование прекратить благотворительную деятельность РПЦ, провести мероприятия, направленные на полное прекращение заявлений приходских общин об открытии храмов. В августе 1959 года список ограничительных мер пополнился требованием ограничения совершение треб духовенством в домах верующих [Шкаровский, 2010, с. 365].

13 января 1960 г. было принято постановление ЦК КПСС «О мерах по ликвидации нарушений духовенством советского законодательства о культах», предусматривавшее отстранение священнослужителей от руководства приходами, сокращение объема правомочий духовенства [Шкаровский, 2010, с. 367]. Вводилась цензура содержания проповедей. В постановлении дополнительно к существующим был включен новый перечень незаконных действий духовенства, в том числе: колокольный звон без разрешения властей, приобретение и строительство недвижимости, материальная помощь маломощным приходам и монастырям, ужесточен заперт на отправление религиозных треб на дому [Чумаченко, 2014, с. 84-85]. При этом перечень нарушений не был открытым, так как содержался в документах секретного характера. Было очевидно, что власть ограничивает РПЦ в правах, которые были ей предоставлены в годы Великой Отечественной войны и первое послевоенное десятилетие.

21 февраля 1960 г. от должности председателя Совета по делам РПЦ при Совете Министров СССР был освобожден Г.Г. Карпов, способствовавший частичной либерализации и развитию государственно-церковных отношений. Председателем Совета был назначен партийный функционер В.А. Куроедов, которому были близки задачи, поставленные ЦК КПСС в религиозной политике [Чумаченко, 2014, с. 84]. Смена руководства в Совете по делам РПЦ также стала своеобразным маркером изменения вектора конфессиональной политики советского государства.

Кроме того, за нарушение законов об отделении церкви от государства и школы от церкви вводилась уголовная ответственность в виде исправительных работ на срок до одного года или штрафа до пятидесяти рублей. За повторное нарушение данных законов и организацию подобных деяний Уголовным Кодексом РСФСР было предусмотрено наказание в виде лишения свободы на срок до трех лет [Уголовный Кодекс РСФСР, 27.10.1960]. При этом полный перечень нарушений данного нормативного акта был определен «постановлением Президиума ВС РСФСР

«16 марта 1961 года было принято постановление Совета Министров СССР «Об усилении контроля за выполнением законодательства о культах»»» [Инструкция, ${ }^{16} .03 .{ }^{1961}$ ]. Согласно этому постановлению, ни одно религиозное объединение не могло приступить к деятельности без регистрации в органах государственной власти. Духовенство устранялось от управления финансово-хозяйственной жизнью приходов, фактически превращалось в наемных работников. Исполкомы местных органов власти могли влиять на формирование состава исполнительных органов приходских общин, воспользовавшись правом отвода неугодных лиц.

В постановлении отмечалось, что «религиозные объединения и служители культов не должны заниматься другой деятельностью, кроме деятельности, направленной на удовлетворение религиозных потребностей верующих. Они не вправе: а) создавать кассы

\footnotetext{
${ }^{94}$ ГАБО. Ф. Р - 140. Оп. 3. Д. 2. Л. 11.
} 
взаимопомощи и заниматься благотворительной деятельностью; б) организовывать санатории и лечебную помощь; в) устраивать экскурсии, детские и спортивные площадки, открывать библиотеки и читальни; г) организовывать какие бы то ни было собрания, кружки и т. п., не имеющие отношения к отправлению культа» [Инструкция, 16.03.1961, с. 79-80].

Для реализации вышеуказанного нормативного акта был принят ряд секретных постановлений, в том числе постановление Совета по делам РПЦ при СМ СССР от 15 ноября 1961 года «О недостатках и мерах улучшения работы по осуществлению постановления Совета Министров СССР от 16 марта 1961 года "Об усилении контроля за выполнением законодательства о культах $\rightarrow{ }^{95}$. В данном постановлении Совета отмечено, что в борьбе за сохранение своего влияния церковники ищут новые формы воздействия на отдельные слои трудящихся. В своих проповедях духовенство особенно старается внушить верующим, что в настоящее время цели религии и коммунизма как никогда тождественны, что новая программа КПСС, принятая 22 съездом, чуть ли не «дар божий», так как «она отражает идеалы Христа», что замечательные достижения СССР в области космоса есть не только проявление разума, гения советского народа, но и действия «божественной силы» ${ }^{96}$. Подвергалась критике работа уполномоченных, которые недостаточно изучают проповедническую деятельность священнослужителей, не принимают должных мер к разоблачению приспособленческих тенденций духовенства ${ }^{97}$. При этом критике подвергались меры грубого администрирования со стороны должностных лиц, представителей местных советских органов, такие как закрытие храмов, снятие с регистрации священнослужителей, ограничение колокольного звона, допросы верующих о доходах и др. ${ }^{98}$

Следствием принятия подобных нормативных актов стала ликвидация паломничества к «святым местам», в государственный фонд подлежало передаче все имущество, приобретенное РПЦ в послевоенные годы. Чумаченко [2014, с. 86] отмечает, что изъятое у религиозных организаций и монастырей недвижимое, а также движимое имущество переводилось на баланс исполкомов местных Советов.

Новая волна жесткой антирелигиозной кампании, инициированная Н.С. Хрущевым, вызывала критику внутренней политики руководства со стороны интеллигенции, возмущала она и широкие массы простых граждан, ожидавших продолжения частичной либерализации советского режима в контексте политики «оттепели» и реформ, предпринятых в 1950-е годы.

Таким образом, грубое административно-командное давление на церковь зачастую давало обратный ожиданиям власти эффект. Молодежь начинала интересоваться историей РПЦ и ее традициями. В этой связи «молодая» идеологическая доктрина советского государства не могла конкурировать с тысячелетней традицией православия, которое на протяжении многих столетий являлось государственно образующей религией и соответствовало менталитету подавляющего большинства населения СССР. Однако руководство страны во главе с Хрущевым считало, что внедрению в быт и сознание советских людей «морального кодекса строителя коммунизма», принятого в качестве важнейшей составной части новой, третьей по счету программы партии на XXII съезде КПСС, мешала РПЦ с ее многовековой исторической, идеологической и культурной традицией.

Ужесточение антирелигиозной кампании совпало со свертыванием «оттепели» и нарастанием волюнтаристских решений Хрущева. Просчеты во внутренней социальноэкономической политике руководство страны пыталось в определенной степени компенсировать ужесточением идеологической и организационной борьбы с РПЦ. Главной целью новой антирелигиозной кампании, развернутой по инициативе Хрущева, было стремление отвлечь внимание общественности от нарастающих проблем, вызванных его гру-

\footnotetext{
${ }^{95}$ ГАБО. Ф. Р - 1179. Оп. 2. Д. 5. Л. 55-63.

${ }^{96}$ Там же. Л. 58.

97 Там же.

98 Там же. 59-60.
} 
быми просчетами в экономическом курсе внутри страны и негативных последствий политических ошибок на международной арене.

\section{Список литературы}

1. Алексеев В.А. 2004. Иллюзии и догмы. М., Издательство политической литературы, 400.

2. Васильева О.Ю. 2004. Русская Православная Церковь и Второй Ватиканский Собор. М., Лепта, 380.

3. Васильева О.Ю. 2001. Русская Православная Церковь в политике советского государства в 1943-1948 гг. М., Институт российской истории РАН, 456.

4. Дорош А.А. 2018. Государственная политика советской власти в отношении церкви и религии в 1941-1964 гг. (по материалам Воронежской области). Автореферат дис. ... канд. ист. наук. Белгород, 27.

5. Законодательство о религиозных культах: сборник материалов и документов. 1971. М., Юридическая литература, 210.

6. Инструкция по применению законодательства о культах (утверждена постановлением Совета по делам религиозных культов при Совете Министров СССР и постановлением Совета по делам русской православной церкви при Совете Министров СССР от 16 марта 1961 г.). В кн.: Законодательство о религиозных культах: сборник материалов и документов. 1971. М., Юридическая литература, 77-87.

7. Марченко А.Н. 2008. Хрущевская церковная реформа и ее влияние на внутрицерковную жизнь по материалам уральского региона: 1958-1964 гг. Дис. ... докт. ист. наук. Москва, 392.

8. Маслова И.И. 2005. Эволюция вероисповедной политики советского государства и деятельности Русской Православной Церкви (1953-1991). Автореф. дис. ... докт. ист. наук. М., 46.

9. Одинцов М.И. 2002. Русская православная церковь в XX веке: история, взаимоотношения с государством и обществом. М., РОИР, 312.

10. Постановление Президиума ВС РСФСР «О применении статьи 142 Уголовного Кодекса РСФСР» от 18.03.1966 г. В кн.: Русская Православная Церковь в советское время (1917-1961 гг.). 1995. Сост. Штриккер Г.М., Пропилеи, 257-258.

11. Пыжиков А.В. 2002. Хрущевская «оттепель». М., ОЛМА-ПРЕСС, 714.

12. Постановление ЦК КПСС «Об ошибках в проведении научно-атеистической пропаганды среди населения» от 10 ноября 1954 года. В кн.: КПСС в резолюциях, в решениях съездов, конференций и пленумов ЦК. 1985. Т. 8.: 1946-1955. М., Ин-т марксизма-ленинизма при ЦК КПСС, 446-450. URL: http://elib.shpl.ru/ru/nodes/8616-t-8-1946-19551985\#mode/inspect/page/450/zoom/4 (дата обращения 11.03.2019)

13. Русская православная церковь в советское время (1917-1991 гг.): Материалы и документы по истории отношений между государством и церковью. В 2 кн. 1995. Сост. Штриккер Г.М., Пропилеи, 400.

14. Растимешина Т.В. 2012. Политика российского государства в отношении культурного наследия церкви. Автореферат дис. ... доктора полит. наук. Москва, 407.

15. Уголовный Кодекс РСФСР. 27.10.1960 г. Ст. 142 «Нарушение закона об отделении церкви от государства и школы от церкви» (утратила силу). В кн.: Законодательство о религиозных культах: сборник материалов и документов. 1971. М., Юридическая литература, 197.

16. Фурман Д.Е. 2011. Избранное. М., Территория будущего, 329.

17. Цыпин В.А. 1994. История Русской Православной Церкви, 1917-1990: Учебник для православных духовных семинарий. М., Изд. Дом «Хроника», 251.

18. Цыпин В. 1997. История Русской церкви. 1917-1997. М., Издательство СпасскоПреображенского Валаамского монастыря, 831.

19. Чумаченко Т.А. 2014. Государство и Русская Православная Церковь в 1958-1964 годах: новая политическая война с религией, церковью, верующими. Вестник Челябинского государственного университета. № 19 (348). Право. Вып. 39: 83. URL: https://cyberleninka.ru/article/v/gosudarstvo-i-russkaya-pravoslavnaya-tserkov-v-1958-1964-godahnovaya-politicheskaya-voyna-s-religiey-tserkovyu-i-veruyuschimi (Дата обращения 17.02.2019).

20. Чумаченко Т.А. 1999. Государство, православная церковь, верующие, 1941-1961 гг. М., АИРО-ХХ, 247.

21. Шкаровский М.В. 2018. Антирелигиозные гонения 1958-1964 гг. в Ленинградской епархии и противостояние им митрополита Никодима (Ротова). Вестник исторического общества. 2: 19-33. DOI: 
10.24411/2587-8425-2018-10012 URL: https://cyberleninka.ru/article/n/antireligioznye-goneniya-1958-1964gg-v-leningradskoy-eparhii-i-protivostoyanie-im-mitropolita-nikodima-rotova (дата обращения 19.01.2019).

22. Шкаровский М.В. 2010. Русская Православная Церковь в XX веке. М.: Вече, Лепта, 480.

23. Шкаровский М.В. 1999. Русская Православная Церковь при Сталине и Хрущеве (государственно-церковные отношения в СССР в 1939-1964 годах). М., Крутицкое патриаршее подворье, Общество любителей церковной истории, 400.

\section{References}

1. Alekseev V.A. 2004. Illyuzii i dogmy [Illusions and dogmas]. M., Political Literature Publishing House, 400.

2. Vasil'eva O.Yu. 2004. Russkaya Pravoslavnaya Tserkov' i Vtoroy Vatikanskiy Sobor [Russian Orthodox Church and the Second Vatican Council]. M., Lepta, 380.

3. Vasil'eva O.Yu. 2001. Russkaya Pravoslavnaya Tserkov' v politike sovetskogo gosudarstva v 1943-1948 gg. [The Russian Orthodox Church in the politics of the Soviet state in 1943-1948]. M., Institute of Russian History, Russian Academy of Sciences (RAS), 456.

4. Dorosh A.A. 2018. Gosudarstvennaya politika sovetskoy vlasti v otnoshenii tserkvi i religii v 1941-1964 gg. (po materialam Voronezhskoy oblasti) [State policy of the Soviet government in relation to the church and religion in 1941-1964 (based on materials from the Voronezh region)]. Abstract. dis. ... kand. ist. nauk. Belgorod, 27.

5. Zakonodatel'stvo o religioznykh kul'takh: sbornik materialov i dokumentov [Legislation on religious cults: a collection of materials and documents]. 1971. M., Yuridicheskaya literatura, 210.

6. Instruktsiya po primeneniyu zakonodatel'stva o kul'takh (utverzhdena postanovleniem Soveta po delam religioznykh kul'tov pri Sovete Ministrov SSSR i postanovleniem Soveta po delam russkoy pravoslavnoy tserkvi pri Sovete Ministrov SSSR ot 16 marta 1961 g.) [Instructions on the application of the legislation on cults (approved by the decree of the Council for Religious Cults under the Council of Ministers of the USSR and the decree of the Council for Russian Orthodox Church under the Council of Ministers of the USSR of March 16, 1961)]. V kn.: Zakonodatel'stvo o religioznykh kul'takh: sbornik materialov i dokumentov. 1971. M., Yuridicheskaya literatura, 77-87. : Legislation on Religious Cults: A Collection of Materials and Documents.

7. Marchenko A.N. 2008. Khrushchevskaya tserkovnaya reforma i ee vliyanie na vnutritserkovnuyu zhizn' po materialam ural'skogo regiona: 1958-1964 gg. [Khrushchev's church reform and its impact on church life based on materials from the Urals region: 1958-1964]. Dis. ... dokt. ist. nauk. Moskva, 392.

8. Maslova I.I. 2005. Evolyutsiya veroispovednoy politiki sovetskogo gosudarstva i deyatel'nosti Russkoy Pravoslavnoy Tserkvi (1953-1991) [The evolution of the religious policy of the Soviet state and the activities of the Russian Orthodox Church (1953-1991)]. Abstract. dis. ... dokt. ist. nauk. M., 46.

9. Odintsov M.I. 2002. Russkaya pravoslavnaya tserkov' v XX veke: istoriya, vzaimootnosheniya s gosudarstvom i obshchestvom [The Russian Orthodox Church in the twentieth century: history, relations with the state and society]. M., RARR, 312.

10. Postanovlenie Prezidiuma VS RSFSR «O primenenii stat'i 142 Ugolovnogo Kodeksa RSFSR» ot 18.03.1966 g. [Decree of the Presidium of the Supreme Soviet of the RSFSR «On the Application of Article 142 of the Criminal Code of the RSFSR» of March 18, 1966.]. V kn.: Russkaya Pravoslavnaya Tserkov' v sovetskoe vremya (1917-1961 gg.) [The Russian Orthodox Church in Soviet times (1917-1961)]. 1995. Sost. Shtrikker G.M., Propilei, 257-258.

11. Pyzhikov A.B. 2002. Khrushchevskaya «ottepel'»[Khrushchev‘s «thaw»]. M., OLMAPRESS, 714.

12. Postanovlenie TsK KPSS «Ob oshibkakh v provedenii nauchno-ateisticheskoy propagandy sredi naseleniya» ot 10 noyabrya 1954 goda [The resolution of the CPSU Central Committee «On Errors in Conducting Scientific-Atheistic Propaganda among the Population» of November 10, 1954]. V kn.: KPSS v rezolyutsiyakh, $\mathrm{v}$ reshe-niyakh s"ezdov, konferentsiy i plenumov TsK [CPSU in resolutions, in decisions of congresses, conferences and plenums of the Central Committee]. 1985. T. 8.: 1946-1955. M., In-t marksizma-leninizma pri TsK KPSS, 446-450. URL: http://elib.shpl.ru/ru/nodes/8616-t-8-19461955-1985\#mode/inspect/page/450/zoom/4 (accessed: 11.03.2019).

13. Russkaya pravoslavnaya tserkov' v sovetskoe vremya (1917-1991 gg.): Materialy i dokumenty po istorii otnosheniy mezhdu gosudarstvom i tserkov'yu [Russian Orthodox Church in Soviet times (1917-1991): Materials and documents on the history of relations between the state and the church]. V 2 kn. 1995. Sost. Shtrikker G.M., Propilei, 400. 
14. Rastimeshina T.V. 2012. Politika rossiyskogo gosudarstva v otnoshenii kul'turnogo naslediya tserkvi [The policy of the Russian state regarding the cultural heritage of the church]. Abstract. dis. ... doktora polit. nauk. Moskva, 407.

15. Ugolovnyy Kodeks RSFSR. 27.10.1960 g. St. 142 «Narushenie zakona ob otdelenii tserkvi ot gosudarstva i shkoly ot tserkvi» (utratila silu) [The Criminal Code of the RSFSR. 10/27/1960 Art. 142 «Violation of the law on the separation of the church from the state and the school from the church» (expired)]. V kn.: Zakonodatel'stvo o religioznykh kul'takh: sbornik materialov i dokumentov [Legislation on Religious Cults: A Collection of Materials and Documents]. 1971. M., Yuridicheskaya literatura, 197.

16. Furman D.E. 2011. Izbrannoe. [Favorites]. M., Territory of the Future, 329.

17. Tsypin V.A. 1994. Istoriya Russkoy Pravoslavnoy Tserkvi, 1917-1990: Uchebnik dlya pravoslavnykh dukhovnykh seminariy [History of the Russian Orthodox Church, 1917-1990: A textbook for Orthodox theological seminaries]. M., Publishing House «Chronicle», 251.

18. Tsypin V. 1997. Istoriya Russkoy tserkvi. 1917-1997 [The History of the Russian Church. 1917-1997]. M., Spassko-Preobrazhensky Valaam Monastery Publishing House, 831.

19. Chumachenko T.A. 2014. Gosudarstvo i Russkaya Pravoslavnaya Tserkov' v 1958-1964 godakh: novaya politicheskaya voyna s religiey, tserkov'yu, veruyushchimi. Vestnik Chelyabinskogo gosudarstvennogo universiteta. № 19 (348). Pravo. Vyp. 39: 83 [The State and the Russian Orthodox Church in 1958-1964: a new political war with religion, the church, and believers. Bulletin of Chelyabinsk State University. No. 19 (348). Right. Vol. 39: 83]. URL: https://cyberleninka.ru/article/v/gosudarstvo-irusskaya-pravoslavnaya-tserkov-v-1958-1964-godah-novaya-politicheskaya-voyna-s-religiey-tserkovyui-veruyuschimi (accessed: 17.02.2019).

20. Chumachenko T.A. 1999. Gosudarstvo, pravoslavnaya tserkov', veruyushchie, 1941-1961 gg. [State, Orthodox Church, believers, 1941-1961]. M., AIRO-XX, 247.

21. Shkarovskiy M.V. 2018. Antireligioznye goneniya 1958-1964 gg. v Leningradskoy eparkhii i protivostoyanie im mitropolita Nikodima (Rotova). Vestnik istoricheskogo obshchestva. [Antireligious persecution of 1958-1964 in the Leningrad diocese and the confrontation by Metropolitan Nicodemus (Rotov). Bulletin of a historical society]. 2: 19-33. DOI: 10.24411/2587-8425-2018-10012 URL: https://cyberleninka.ru/article/n/antireligioznye-goneniya-1958-1964-gg-v-leningradskoy-eparhii-iprotivostoyanie-im-mitropolita-nikodima-rotova (accessed: 19.01.2019).

22. Shkarovskiy M.V. 2010. Russkaya Pravoslavnaya Tserkov' v XX veke [Russian Orthodox Church in the twentieth century]. M., Veche, Lepta, 480.

23. Shkarovskiy M.V. 1999. Russkaya Pravoslavnaya Tserkov' pri Staline i Khrushcheve (gosudarstvenno-tserkovnye otnosheniya v SSSR v 1939-1964 godakh) [The Russian Orthodox Church under Stalin and Khrushchev (state-church relations in the USSR in 1939-1964)]. M., Krutitsky Patriarchal Compound, Society of Church History Fans, 400.

\section{Ссылка для цитирования статьи Link for article citation}

Остроухова Н.В. 2020. Особенности нормативно-правового регулирования государственно-церковных отношений в ССCP (1953-1963). Via in tempore. История. Политология, 47(1): 160-169. DOI 10.18413/2687-0967-2020-47-1-160-169

Ostroukhova N.V. 2020. Peculiarities of the normative-legal regulation of the state-church relations in the USSR (1953-1963). Via in tempore. History and political science, 47(1): 160-169 (in Russian). DOI 10.18413/2687-0967-2020-47-1-160-169 